\title{
HUBUNGAN ANTARA BAURAN PEMASARAN DENGAN LOYALITAS PASIEN RAWAT JALAN DI RUMAH SAKIT DAERAH KALISAT KABUPATEN JEMBER TAHUN 2017
}

\section{Relation of Marketing Mix and Outpatient Loyalty at Kalisat Regional Hospital Jember District 2017}

\author{
${ }^{1}$ Yuliasfa Sirrul Hayati, ${ }^{2}$ Christyana Sandra, ${ }^{3}$ Yennike Tri Herawati \\ ${ }^{123}$ Bagian Administrasi dan Kebijakan Kesehatan \\ Fakultas Kesehatan Masyarakat Universitas Jember \\ Jalan Kalimantan 37, Jember 68121 \\ e-mail korespondensi : christyana sandra@yahoo.com
}

\begin{abstract}
Marketing mix in hospital is a group of controllable variables that can be used by hospitals to influence the reaction of service buyers. The marketing mix consisting of 7P (Product, Price, Place, Promotion, Process, Person, and Physical Evidence) can affect patient loyalty. This study aims to analyze the relationship between marketing mix and patient loyalty. The study method used is analytic with cross sectional design. The sample of study is 90 respondents using systematic random sampling technique. The result showed that most respondents rated the product mix (82\%), the price mix (81\%), the place mix (72\%), the process mix (79\%), the mix (84\%), and the physical evidence mix (82\%) is good. However, most respondents rated promotion mix (92\%) classified as less good. Based on the results, it is concluded that there is no significant relation between place mix and physical proof mix with patient loyalty, and there is significant relation between product mix, price mix, promotion mix, and process mix with patient loyalty. To increase loyalty patients can improve or maintain product mix, price mix, promotion mix, process mix, and people mix.
\end{abstract}

Keywords : marketing mix, patient loyalty

\begin{abstract}
Abstrak
Bauran pemasaran rumah sakit adalah sekelompok variabel yang dapat dikendalikan, yang dapat digunakan oleh rumah sakit untuk mempengaruhi reaksi para pembeli pelayanan. Bauran pemasaran yang terdiri dari 7P (Produk, Harga, Tempat, Promosi, Proses, Orang, dan Bukti Fisik) dapat mempengaruhi loyalitas pasien. Penelitian ini bertujuan untuk menganalisis hubungan antara bauran pemasaran dengan loyalitas pasien. Metode penelitian yang digunakan adalah analitik dengan desain cross sectional. Sampel penelitian berjumlah 90 responden, dimana pengambilan sampel menggunakan teknik systematic random sampling. Hasil analisis menunjukkan bahwa sebagian besar responden menilai bauran produk (82\%), bauran harga (81\%), bauran tempat $(72 \%)$, bauran proses (79\%), bauran orang (84\%), dan bauran bukti fisik (82\%) tergolong baik. Namun, sebagian besar responden menilai bauran promosi (92\%) tergolong kurang baik. Berdasarkan hasil penelitian disimpulkan bahwa tidak ada hubungan yang significan 123 Yuliasfa Sirrul Hayati, Christyana Sandra, dan Yennike Tri Herawati adalah Bagian Administrasi dan Kebijakan Kesehatan Fakultas Kesehatan Masyarakat Universitas Jember
\end{abstract}


antara bauran tempat dan bauran bukti fisik dengan loyalitas pasien, dan ada hubungan yang significan antara bauran produk, bauran harga, bauran promosi, dan bauran proses dengan loyalitas pasien. Untuk meningkatkan loyalitas pasien dapat meningkatkan atau mempertahankan bauran produk, bauran harga, bauran promosi, bauran proses, dan bauran orang.

Kata kunci : bauran pemasaran, loyalitas pasien

\section{PENDAHULUAN}

Dewasa ini, jumlah rumah sakit yang semakin meningkat membuat setiap rumah sakit saling bersaing untuk mendapatkan pelanggan. Untuk menghadapi persaingan global antar rumah sakit di Indonesia, rumah sakit perlu memperhatikan pemasaran rumah sakit. Pemasaran harus memperhatikan antara kebutuhan, keinginan dan permintaan pelanggan agar tujuan pemasaran tercapai [1].

Salah satu strategi pemasaran rumah sakit yang dapat digunakan dalam menghadapi persaingan global adalah bauran pemasaran (marketing mix). Bauran pemasaran mempunyai pengaruh yang besar terhadap tindakan konsumen dalam membeli suatu produk jasa [2]. Oleh karena itu perusahaan harus dapat menyesuaikan antara bauran pemasaran dengan kebutuhan dan keinginan konsumen agar dapat menarik lebih banyak konsumen [2]. Berdasarkan data Dinas Kesehatan Kabupaten Jember, jumlah kunjungan pasien rawat jalan pada 3 rumah sakit pemerintah yaitu RSD dr.Soebandi, RSD Balung, dan RSD Kalisat mengalami fluktuatif.

Jumlah kunjungan pasien rawat jalan di RSD Kalisat paling rendah diantara 3 rumah sakit pemerintah yang berada di Kabupaten Jember. Capaian kunjungan rawat jalan tahun 2014 berjumlah 15.949 pasien, tahun 2015 berjumlah 15.849 pasien, tahun 2016 berjumlah 22.685 pasien, dan tahun 2017 berjumlah 29.235 pasien [3]. Sedangkan jumlah kunjungan pasien lama rawat jalan pada tahun 2014 berjumlah 5.321 pasien, tahun 2015 berjumlah 3.138 pasien, dan tahun 2016 berjumlah 11.675 pasien [3]. Berdasarkan jumlah kunjungan tersebut, maka Rumah Sakit Daerah Kalisat perlu untuk memperbaiki fasilitas, pelayanan serta kegiatan pemasaran yang telah dilaksanakan.

Loyalitas pasien merupakan salah satu inti yang harus diupayakan oleh rumah sakit. Hal ini karena peningkatan loyalitas pasien dapat memberikan keuntungan jangka panjang [4]. Bentuk perilaku loyalitas terhadap rumah sakit bermacam-macam seperti menggunakan layanan jasa yang lain dari rumah sakit (general check up, konsultasi kesehatan, pemeriksaan laboratorium, pemeriksaan radiologi), menyampaikan hal-hal positif mengenai rumah sakit, dan merekomendasi rumah sakit tersebut ke pihak lainnya [5].

Menurut Swastha dan Irawan, bauran pemasaran yang meliputi produk, harga, tempat, promosi, orang, proses, dan bukti fisik berpengaruh terhadap loyalitas pasien. Pelayanan yang bermutu akan membuat pasien loyal akan pelayanan kita, yaitu bila di suatu saat membutuhkan pelayanan kembali atau menjadi advokator atau pemasar yang tidak dibayar [6]. Penelitian ini bertujuan untuk mengetahui hubungan antara 
bauran pemasaran dengan loyalitas pasien rawat jalan Rumah Sakit Daerah Kalisat Kabupaten Jember.

\section{Metode Penelitian}

Penelitian ini bersifat analitik dengan metode cross sectional karena peneliti bertujuan menganalisis hubungan antara bauran pemasaran sebagai variabel bebas dengan loyalitas pasien sebagai variabel terikat. Populasi dalam penelitian ini adalah jumlah kunjungan pasien rawat jalan dari bulan Januari sampai bulan Mei yang berobat di RSD Kalisat Kabupaten Jember pada tahun 2017 yang berjumlah 7495 pasien.

Sampel penelitian ini menggunakan teknik pengambilan sampel dengan systematic random sampling (pengambilan sampel secara acak sistematik) sebanyak 90 responden.
Penelitian ini menggunakan data primer yang diperoleh melalui wawancara dengan kuesioner, sedangkan data sekunder diperoleh melalui profil Dinas Kesehatan Kabupaten Jember dan profil Rumah Sakit Daerah Kalisat. Data yang diperoleh akan dianalisis menggunakan uji Rho Spearman $(\alpha=0,05)$.

\section{HASIL PENELITIAN}

\section{Distribusi Bauran Pemasaran 7P}

Bauran pemasaran dalam penelitian ini meliputi bauran produk, bauran harga, bauran tempat, bauran promosi, bauran proses, bauran orang, dan bauran bukti fisik.

Tabel 1. Distribusi Bauran Pemasaran 7P di Rumah Sakit Daerah Kalisat Kabupaten Jember

\begin{tabular}{|c|c|c|c|c|c|}
\hline No & $\begin{array}{c}\text { Bauran } \\
\text { Pemasaran }\end{array}$ & $\mathbf{n}$ & $\%$ & & \\
\hline \multirow[t]{4}{*}{1.} & Bauran Produk & & & & \\
\hline & Baik & 74 & 82 & & \\
\hline & Kurang Baik & & & 16 & 18 \\
\hline & Total & & & 90 & 100 \\
\hline \multirow[t]{4}{*}{2.} & Bauran Harga & & & & \\
\hline & Baik & & & 73 & 81 \\
\hline & Kurang Baik & & & 17 & 19 \\
\hline & Total & & & 90 & 100 \\
\hline \multirow[t]{4}{*}{3.} & Bauran Tempat & & & & \\
\hline & Baik & & & 65 & 72 \\
\hline & Kurang Baik & & & 25 & 28 \\
\hline & Total & & & 90 & 100 \\
\hline \multirow[t]{4}{*}{4.} & Bauran Promosi & & & & \\
\hline & Baik & & & 7 & 8 \\
\hline & Kurang Baik & & & 83 & 92 \\
\hline & Total & & & 90 & 100 \\
\hline \multirow[t]{4}{*}{5.} & Bauran Proses & & & & \\
\hline & Baik & & & 71 & 79 \\
\hline & Kurang Baik & & & 19 & 21 \\
\hline & Total & & & 90 & 100 \\
\hline
\end{tabular}




\begin{tabular}{llll}
\hline No & $\begin{array}{c}\text { Bauran } \\
\text { Pemasaran }\end{array}$ & $\mathbf{\%}$ & \\
\hline 6. & Bauran Orang & 76 & \\
& Baik & 14 & 84 \\
& Kurang Baik & 90 & 16 \\
\hline$\quad$ Total & & 100 \\
\hline $7 . \quad$ Bauran Bukti Fisik & 74 & 82 \\
& Baik & 16 & 18 \\
& Kurang Baik & 90 & 100 \\
\hline
\end{tabular}

Tabel 1 menunjukkan bahwa sebagian besar responden menilai bauran produk baik yaitu sebanyak 74 responden (82\%). Bauran harga baik yaitu sebanyak 73 responden (81\%). Bauran tempat baik yaitu sebanyak 65 responden (72\%). Bauran promosi kurang baik yaitu sebanyak 83 responden (92\%). Bauran proses baik yaitu sebanyak 71 responden (79\%).
Bauran orang baik yaitu sebanyak 76 responden (84\%). Bauran bukti fisik baik yaitu sebanyak 74 responden (82\%).

\section{Distribusi Loyalitas Pasien}

Pengumpulan data loyalitas pasien dilakukan dengan kuesioner, yang dikelompokkan kedalam dua kategori yaitu loyal dan kurang loyal

Tabel 2. Distribusi Loyalitas Pasien Rawat Jalan di Rumah Sakit Daerah Kalisat Kabupaten Jember

\begin{tabular}{ccc}
\hline \multicolumn{1}{c}{ Loyalitas Pasien } & n & \% \\
\hline Loyal & 30 & 33 \\
Kurang Loyal & 60 & 67 \\
\hline \multicolumn{1}{c}{ Total } & 90 & 100 \\
\hline
\end{tabular}

Tabel 2 menunjukkan bahwa sebagian besar responden kurang loyal terhadap instalasi rawat jalan RSD Kalisat sebanyak 60 responden (67\%), sedangkan yang loyal sebanyak 30 responden (33\%).
Hubungan antara Bauran Produk dengan Loyalitas Pasien

Pengumpulan data loyalitas pasien dan bauran produk dilakukan dengan kuesioner. Berikut tabel hubungan antara bauran produk dengan loyalitas pasien

Tabel 3. Hubungan antara Bauran Produk dengan Loyalitas Pasien

\begin{tabular}{|c|c|c|c|c|c|c|}
\hline \multirow{3}{*}{ Bauran Produk } & \multicolumn{4}{|c|}{ Loyalitas Pasien } & \multicolumn{2}{|c|}{ Total } \\
\hline & \multicolumn{2}{|c|}{ Loyal } & \multicolumn{2}{|c|}{ Kurang Loyal } & \multirow[b]{2}{*}{$\mathrm{n}$} & \multirow[b]{2}{*}{$\%$} \\
\hline & & & & $\%$ & & \\
\hline Baik & 28 & 31 & 46 & 51 & 74 & 82 \\
\hline Kurang Baik & 2 & 2 & 14 & 16 & 16 & 18 \\
\hline Total & 30 & 33 & 60 & 67 & 90 & 100 \\
\hline
\end{tabular}


Tabel 3 menunjukkan bahwa sebagian besar responden menilai bauran produk tergolong baik, namun kurang loyal sebanyak 46 responden (51\%). Hasil penelitian juga menunjukkan bahwa responden yang menilai bauran produk tergolong baik dan loyal sebanyak 28 responden (31\%). Berdasarkan hasil analisis tersebut menunjukkan bahwa bauran produk secara signifikan berhubungan dengan loyalitas pasien.

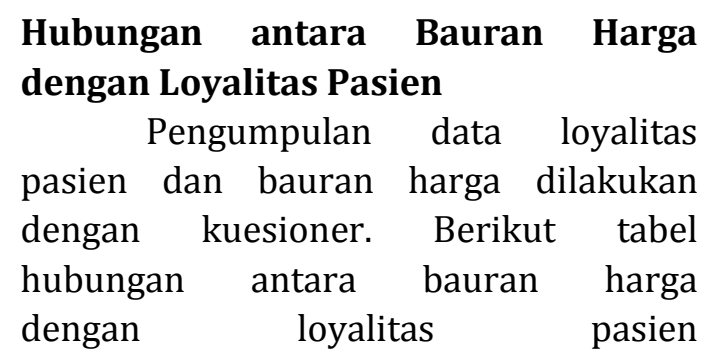

Tabel 4. Hubungan antara Bauran Harga dengan Loyalitas Pasien

\begin{tabular}{|c|c|c|c|c|c|c|}
\hline \multirow{3}{*}{ Bauran Harga } & \multicolumn{4}{|c|}{ Loyalitas Pasien } & \multirow{2}{*}{\multicolumn{2}{|c|}{ Total }} \\
\hline & \multicolumn{2}{|c|}{ Loyal } & \multicolumn{2}{|c|}{ Kurang Loyal } & & \\
\hline & & & $\mathrm{n}$ & & $\mathrm{n}$ & $\%$ \\
\hline Baik & 30 & 33 & 43 & 48 & 73 & 81 \\
\hline Kurang Baik & 0 & 0 & 17 & 19 & 17 & 19 \\
\hline Total & 30 & 33 & 60 & 67 & 90 & 100 \\
\hline
\end{tabular}

Tabel 4 menunjukkan bahwa sebagian besar responden menilai bauran harga tergolong baik, namun kurang loyal sebanyak 43 responden (48\%). Responden yang menilai bauran

\section{Hubungan antara Bauran Tempat dengan Loyalitas Pasien}

Pengumpulan data loyalitas pasien dan bauran tempat dilakukan harga tergolong baik dan loyal sebanyak 30 responden (33\%). Berdasarkan hasil analisis tersebut menunjukkan bahwa bauran harga secara signifikan berhubungan dengan loyalitas pasien.

dengan kuesioner. Berikut tabel hubungan antara bauran tempat dengan loyalitas

pasien

Tabel 5. Hubungan antara Bauran Tempat dengan Loyalitas Pasien

\begin{tabular}{|c|c|c|c|c|c|c|}
\hline \multirow{3}{*}{ Bauran Tempat } & \multicolumn{4}{|c|}{ Loyalitas Pasien } & \multirow{2}{*}{\multicolumn{2}{|c|}{ Total }} \\
\hline & \multicolumn{2}{|c|}{ Loyal } & \multicolumn{2}{|c|}{ Kurang Loyal } & & \\
\hline & n $\%$ & & $\%$ & & $\mathrm{n}$ & $\%$ \\
\hline Baik & 18 & 20 & 47 & 52 & 65 & 72 \\
\hline Kurang Baik & 12 & 13 & 13 & 15 & 25 & 28 \\
\hline Total & 30 & 33 & 60 & 67 & 90 & 100 \\
\hline
\end{tabular}


Tabel 5 menunjukkan bahwa sebagian besar responden menilai bauran tempat tergolong baik, namun kurang loyal sebanyak 47 responden (52\%). Hasil penelitian juga menunjukkan bahwa responden yang menilai bauran tempat tergolong baik dan loyal sebanyak 18 responden (20\%). Berdasarkan hasil analisis tersebut menunjukkan bahwa bauran tempat secara significan tidak berhubungan dengan loyalitas pasien.

\section{Hubungan antara Bauran Promosi dengan Loyalitas Pasien}

Pengumpulan data loyalitas pasien dan bauran promosi dilakukan dengan kuesioner. Berikut tabel hubungan antara bauran promosi dengan loyalitas pasien

Tabel 6. Hubungan antara Bauran Promosi dengan Loyalitas Pasien

\begin{tabular}{|c|c|c|c|c|c|c|}
\hline \multirow{3}{*}{ Bauran Promosi } & \multicolumn{4}{|c|}{ Loyalitas Pasien } & \multirow{2}{*}{\multicolumn{2}{|c|}{ Total }} \\
\hline & \multirow{2}{*}{\multicolumn{2}{|c|}{$\begin{array}{l}\text { Loyal } \\
\mathrm{n} \% \\
\end{array}$}} & \multicolumn{2}{|c|}{ Kurang Loyal } & & \\
\hline & & & & $\%$ & $\mathrm{n}$ & $\%$ \\
\hline Baik & 2 & 2 & 5 & 6 & 7 & 8 \\
\hline Kurang Baik & 28 & 31 & 55 & 61 & 83 & 92 \\
\hline Total & 30 & 33 & 60 & 67 & 90 & 100 \\
\hline
\end{tabular}

Tabel 6 menunjukkan bahwa sebagian besar responden menilai bauran promosi kurang baik dan kurang loyal sebanyak 55 responden (61\%). Hasil penelitian juga menunjukkan bahwa responden yang menilai bauran promosi kurang baik, namun loyal sebanyak 28 responden (31\%). Berdasarkan hasil analisis tersebut menunjukkan bahwa bauran promosi secara signifikan berhubungan dengan loyalitas pasien.

\begin{abstract}
Hubungan antara Bauran Proses dengan Loyalitas Pasien

Pengumpulan data loyalitas pasien dan bauran proses dilakukan dengan kuesioner. Berikut tabel hubungan antara bauran proses dengan loyalitas pasien
\end{abstract}

Tabel 7. Hubungan antara Bauran Proses dengan Loyalitas Pasien

\begin{tabular}{|c|c|c|c|c|c|c|}
\hline \multirow{3}{*}{ Bauran Proses } & \multicolumn{4}{|c|}{ Loyalitas Pasien } & \multirow{2}{*}{\multicolumn{2}{|c|}{ Total }} \\
\hline & \multirow{2}{*}{\multicolumn{2}{|c|}{$\begin{array}{c}\text { Loyal } \\
\mathrm{n} \%\end{array}$}} & \multicolumn{2}{|c|}{ Kurang Loyal } & & \\
\hline & & & & $\%$ & \multicolumn{2}{|c|}{$\mathrm{n} \quad \%$} \\
\hline Baik & 30 & 33 & 41 & 46 & 71 & 79 \\
\hline Kurang Baik & 0 & 0 & 19 & 21 & 19 & 21 \\
\hline Total & 30 & 33 & 60 & 67 & 90 & 100 \\
\hline
\end{tabular}

Tabel 7 menunjukkan bahwa sebagian besar responden menilai bauran proses tergolong baik, namun kurang loyal sebanyak 41 responden
(46\%). Hasil penelitian juga menunjukkan bahwa responden menilai bauran proses tergolong baik dan loyal sebanyak 30 responden (33\%). Berdasarkan hasil analisis tersebut 
menunjukkan bahwa bauran proses secara signifikan berhubungan dengan loyalitas pasien.

$\begin{aligned} & \text { Hubungan antara Bauran } \\
& \text { dengan Loyalitas Pasien }\end{aligned}$
\begin{tabular}{lrr} 
Pengumpulan data loyalitas \\
pasien dan bauran orang dilakukan \\
dengan & \multicolumn{2}{c}{ kuesioner. Berikut tabel } \\
hubungan antara bauran & orang \\
dengan & loyalitas & pasien
\end{tabular}

Tabel 8. Hubungan antara Bauran Orang dengan Loyalitas Pasien

\begin{tabular}{|c|c|c|c|c|c|c|}
\hline \multirow{3}{*}{ Bauran Orang } & \multicolumn{4}{|c|}{ Loyalitas Pasien } & \multicolumn{2}{|c|}{ Total } \\
\hline & \multicolumn{2}{|c|}{ Loyal } & \multicolumn{2}{|c|}{ Kurang Loyal } & & \\
\hline & & & & & & \\
\hline Baik & 27 & 30 & 49 & 55 & 76 & 85 \\
\hline Kurang Baik & 3 & 3 & 11 & 12 & 14 & 15 \\
\hline Total & 30 & 33 & 60 & 67 & 90 & 100 \\
\hline
\end{tabular}

Tabel 8 menunjukkan bahwa sebagian besar responden menilai bauran orang tergolong baik, namun kurang loyal sebanyak 49 responden (55\%). Hasil penelitian juga menunjukkan bahwa responden menilai bauran orang tergolong baik dan loyal sebanyak 27 responden (30\%). Berdasarkan hasil analisis tersebut menunjukkan bahwa bauran orang secara signifikan berhubungan dengan loyalitas pasien.

\section{Hubungan antara Bauran Bukti Fisik dengan Loyalitas Pasien}

Pengumpulan data loyalitas pasien dan bauran bukti fisik dilakukan dengan kuesioner. Berikut tabel hubungan antara bauran bukti fisik dengan loyalitas pasien

Tabel 9. Hubungan antara Bauran Bukti Fisik dengan Loyalitas Pasien

\begin{tabular}{|c|c|c|c|c|c|c|}
\hline \multirow{3}{*}{$\begin{array}{c}\text { Bauran Bukti } \\
\text { Fisik }\end{array}$} & \multicolumn{4}{|c|}{ Loyalitas Pasien } & \multirow{2}{*}{\multicolumn{2}{|c|}{ Total }} \\
\hline & \multicolumn{2}{|c|}{ Loyal } & \multicolumn{2}{|c|}{ Kurang Loyal } & & \\
\hline & n \% & & $\mathrm{n}$ & $\%$ & $\mathrm{n}$ & $\%$ \\
\hline Baik & 24 & 27 & 50 & 55 & 74 & 82 \\
\hline Kurang Baik & 6 & 7 & 10 & 11 & 16 & 18 \\
\hline Total & 30 & 33 & 60 & 67 & 90 & 100 \\
\hline
\end{tabular}

Tabel 9 menunjukkan bahwa sebagian besar responden menilai bauran bukti fisik tergolong baik, namun kurang loyal sebanyak 50 responden (55\%). Hasil penelitian juga menunjukkan bahwa responden yang menilai bauran bukti fisik tergolong baik dan loyal sebanyak 24 responden (27\%). Berdasarkan hasil analisis tersebut menunjukkan bahwa bauran bukti fisik secara signifikan tidak berhubungan dengan loyalitas pasien. 
PEMBAHASAN

\section{Hubungan antara Bauran Produk dengan Loyalitas Pasien}

Berdasarkan hasil penelitian menunjukkan bahwa sebagian besar responden menilai bauran produk termasuk dalam kategori baik tetapi kurang loyal sebanyak 46 responden (51\%). Hasil penelitian ini diperkuat dengan hasil penelitian sebelumnya yang menunjukkan bahwa sebagian besar responden menilai bauran produk tergolong baik (56\%) [7]. Hal ini disebabkan karena pelayanan perawat yang kurang baik, persediaan obatobatan yang kurang lengkap, dan fasilitas penunjang medis yang kurang lengkap saat melayani pasien. Hal ini sejalan dengan teori yaitu pelanggan akan menjadi loyal apabila produk-produk tersebut ditawarkan (dipromosikan) dengan baik [4]. Kemudian penilaian yang baik mengenai produk yang sesuai dengan tingkat baik atau tidaknya kualitas produk yang diberikan dengan kesesuaian harga mendorong pelanggan untuk setia terhadap produk tersebut [8].

Hasil uji statistik dalam penelitian ini menunjukkan ada hubungan antara bauran produk dengan loyalitas pasien rawat jalan dengan nilai $p=0,000<\alpha=0,05$. Hasil penelitian ini sejalan dengan penelitian yang dilakukan oleh Wijayanti (2014) yang menunjukkan $\mathrm{p}=0,000<\alpha=0,05$ [9]. Namun, hasil penelitian ini tidak sejalan dengan penelitian yang dilakukan Poernomo (2009) yang menunjukkan nilai $p=0,604>0,05$ yang berarti bahwa tidak ada hubungan antara bauran produk dengan loyalitas pasien [7].

\section{Hubungan antara Bauran Harga dengan Loyalitas Pasien}

Berdasarkan hasil penelitian menunjukkan bahwa sebagian besar responden menilai bauran harga termasuk dalam kategori baik tetapi kurang loyal sebanyak 43 responden (48\%). Hasil penelitian ini diperkuat dengan hasil penelitian sebelumnya yang menunjukkan bahwa sebagian besar responden menilai bauran harga tergolong baik $(58,7 \%)$ [7]. Hal ini disebabkan karena tarif pelayanan yang terlalu mahal dan tidak sesuai dengan pelayanan yang diberikan pada pasien. Hal ini sejalan dengan teori yaitu bagi pasien, harga yang dibayar bukan hanya tarif pengobatan, tetapi juga biaya lain meliputi biaya transportasi, biaya menunggu, dan upah yang hilang akibat tidak bekerja dikenal dengan willingness to pay [10].

Hasil uji statistik dalam
penelitian ini menunjukkan ada hubungan antara bauran harga dengan loyalitas pasien rawat jalan dengan nilai $p=0,000<\alpha=0,05$. Hasil penelitian ini sejalan dengan penelitian yang dilakukan oleh Wijayanti (2014) yang menunjukkan nilai $\mathrm{p}=0,000<0,05$ [9]. Hasil penelitian ini juga sejalan dengan penelitian yang dilakukan Rengkuan et al (2015) yang menunjukkan nilai $\mathrm{p}=0,000$ $<0,05$ [11].

\section{Hubungan antara Bauran Tempat dengan Loyalitas Pasien}

Sebagian besar responden menilai bauran tempat termasuk dalam kategori baik tetapi kurang loyal sebanyak 47 responden (52\%). Hasil penelitian ini diperkuat dengan hasil penelitian sebelumnya yang menunjukkan bahwa sebagian besar responden menilai bauran tempat tergolong baik $(52,7 \%)$ [7]. Hal ini disebabkan karena kondisi lingkungan yang kurang bersih. Hal ini sejalan dengan teori yaitu Pendapat pelanggan terhadap suatu jasa dapat dipengaruhi oleh suasana yang dibentuk oleh 
eksterior dan interior fasilitas tempat tersebut [11].

Hasil uji statistik dalam penelitian ini menunjukkan tidak ada hubungan antara bauran tempat dengan loyalitas pasien rawat jalan dengan nilai $p=0,598>\alpha=0,05$. Hasil penelitian ini sejalan dengan penelitian yang dilakukan oleh Poernomo (2009) yang menunjukkan nilai $\mathrm{p}=0,062>0,05$ [7]. Hasil penelitian ini juga sejalan dengan Penelitian yang dilakukan oleh Solida (2013) yang menunjukkan nilai $\mathrm{p}=0,690$ $>0,05[12]$.

\section{Hubungan antara Bauran Promosi dengan Loyalitas Pasien}

Sebagian besar responden menilai bauran promosi termasuk dalam kategori kurang baik dan responden kurang loyal sebanyak 55 responden (61\%). Hasil penelitian ini diperkuat dengan hasil penelitian sebelumnya yang menunjukkan bahwa sebagian besar responden menilai bauran promosi tergolong kurang baik (52\%) [7]. Hal ini disebabkan karena media promosi yang kurang lengkap, warga sekitar jarang mendapatkan penyuluhan kesehatan, dan pasien belum mengetahui kegiatan promosi di website. Hal ini sejalan dengan teori yaitu promosi merupakan salah satu faktor penentu keberhasilan suatu program pemasaran [4]. Betapapun berkualitasnya suatu produk, apabila konsumen belum pernah mendengarnya dan tidak yakin bahwa produk tersebut berguna bagi mereka, maka mereka tidak akan membelinya [4].

Hasil uji statistik dalam penelitian ini menunjukkan ada hubungan antara bauran promosi dengan loyalitas pasien rawat jalan dengan nilai $p=0,023<\alpha=0,05$. Hasil penelitian ini sejalan dengan penelitian yang dilakukan oleh Sembor et al (2015) yang menunjukkan nilai $\mathrm{p}=0,011<0,05$ [13].
Namun, hasil penelitian ini tidak sejalan dengan penelitian yang dilakukan oleh Poernomo (2009) yang menunjukkan nilai $\mathrm{p}=0,201>0,05$ yang berarti bahwa tidak ada hubungan antara bauran promosi dengan loyalitas pasien [7].

\section{Hubungan antara Bauran Proses dengan Loyalitas Pasien}

Sebagian besar responden menilai bauran proses termasuk dalam kategori baik tetapi kurang loyal sebanyak 41 responden (46\%). Hasil penelitian ini diperkuat dengan hasil penelitian sebelumnya yang menunjukkan bahwa sebagian besar responden menilai bauran proses tergolong baik (56\%) [12]. Hal ini disebabkan karena proses pendaftaran pasien yang terlalu lama, proses pembayaran pasien yang terlalu lama, proses pembayaran obat pasien yang terlalu lama, tidak ada fasilitas fotokopi, tempat pendaftaran yang kurang nyaman, kurangnya jumlah tenaga pendaftaran dan dokter yang belum tepat waktu dalam melayani pasien. Hal ini sejalan dengan teori yaitu Ada hubungan antara proses dengan loyalitas pasien karena proses mencakup prosedur pemberian pelayanan yang diberikan kepada pasien [11].

Hasil uji statistik menunjukkan ada hubungan antara bauran proses dengan loyalitas pasien rawat jalan dengan nilai $p=0,000<\alpha=0,05$. Hasil penelitian ini sejalan dengan penelitian yang dilakukan oleh Oktavia et al (2016) dengan nilai $\mathrm{p}=0,040<0,05$ [8].

\section{Hubungan antara Bauran Orang dengan Loyalitas Pasien}

Sebagian besar responden menilai bauran orang termasuk dalam kategori baik tetapi kurang loyal sebanyak 49 responden (55\%). Hasil penelitian ini diperkuat dengan hasil 
penelitian sebelumnya yang menunjukkan bahwa sebagian besar responden menilai bauran orang tergolong baik (54\%) [12]. Hal ini disebabkan karena petugas dan dokter yang belum ramah dalam melayani pasien dan belum bisa berkomunikasi baik dengan pasien. Hal ini sejalan dengan teori yaitu petugas adalah semua pelaku yang memainkan sebagian penyajian jasa dan tentunya mempengaruhi loyalitas [11]. Petugas adalah elemen esensial yang penting dalam produksi dan penyelenggaraan pelayanan yang dapat menjadi nilai tambah dan lebih kompetitif [11].

Hasil uji statistik menunjukkan ada hubungan antara bauran orang dengan loyalitas pasien rawat jalan dengan nilai $p=0,002<\alpha=0,05$. Hasil penelitian ini sejalan dengan penelitian yang dilakukan oleh Wijayanti (2014) dengan nilai $p=0,005<0,05$ [9]. Namun, hasil penelitian ini tidak sejalan dengan penelitian yang dilakukan oleh Rengkuan et al (2015) yang menunjukkan bahwa tidak ada hubungan antara bauran orang dengan loyalitas pasien [11].

\section{Hubungan antara Bauran Bukti Fisik dengan Loyalitas Pasien}

Sebagian besar responden

menilai bauran bukti fisik termasuk dalam kategori baik tetapi kurang loyal sebanyak 50 responden (55\%). Hasil penelitian ini diperkuat dengan hasil penelitian sebelumnya yang menunjukkan bahwa sebagian besar responden menilai bauran bukti fisik tergolong baik $(58,7 \%)$ [7]. Hal ini disebabkan karena ruang tunggu yang kurang nyaman, ruang pemeriksaan instalasi yang kurang nyaman, penerangan di ruang tunggu dan ruang pemeriksaan yang kurang baik, toilet yang kurang bersih, dan kondisi peralatan medis yang kurang baik. Hal ini sejalan dengan teori yaitu sarana fisik merupakan salah satu unsur penting dalam bauran pemasaran [4]. Bukti fisik ini bisa dalam berbagai bentuk, misalnya paket pelayanan medical check up, penampilan staf yang rapi dan sopan, seragam petugas, ruang tunggu yang nyaman dan lain-lain [4].

Hasil uji statistik dalam penelitian ini menunjukkan tidak ada hubungan antara bauran bukti fisik dengan loyalitas pasien rawat jalan dengan nilai $p=0,936>\alpha=0,05$. Hasil penelitian ini sejalan dengan penelitian yang dilakukan oleh Solida (2013) dengan nilai $p=1,000>0,05$ [12]. Namun, hasil penelitian ini tidak sejalan dengan penelitian yang dilakukan oleh Wijayanti (2014) yang menunjukkan bahwa ada hubungan antara bauran bukti fisik dengan loyalitas pasien dengan nilai $\mathrm{p}=0,001<0,05$ [9].

\section{Loyalitas Pasien}

Sebagian besar responden memilih kategori kurang loyal terhadap instalasi rawat jalan RSD Kalisat yaitu sebesar 67\%. Penelitian ini sejalan dengan penelitian lain yang dilakukan oleh Asmita (2008) yang menunjukkan sebagian besar responden memilih kategori kurang loyal (54\%) [14]. Namun, hasil penelitian ini tidak sejalan dengan penelitian yang dilakukan oleh Poernomo (2009) yang menunjukkan sebagian besar responden memilih kategori loyal(60,7\%) [7].

\section{SIMPULAN DAN SARAN}

Simpulan pada penelitian ini adalah sebagian besar responden menilai bauran produk, bauran harga, bauran tempat, bauran proses, bauran orang, dan bauran bukti fisik tergolong baik. Namun, sebagian besar responden 
menilai bauran promosi tergolong baik. Sebagian besar responden tergolong kurang loyal terhadap instalasi rawat jalan. Analisis bivariat menunjukkan bahwa tidak ada hubungan yang siginifikan antara bauran tempat dan bauran bukti fisik dengan loyalitas pasien dan ada hubungan yang signifikan antara bauran produk, bauran harga, bauran promosi, bauran proses, dan bauran orang dengan loyalitas pasien.

Berdasarkan hasil kesimpulan, maka saran yang dapat diberikan yaitu meningkatkan bauran pemasaran yang terdiri dari bauran produk, bauran harga, bauran tempat, bauran promosi, bauran orang, bauran proses, dan bauran bukti fisik serta meningkatkan loyalitas pasien rawat jalan. Selain itu, perlu melengkapi fasilitas penunjang medis, menurunkan tarif pelayanan, menjaga kebersihan lingkungan, sering melakukan kegiatan penyuluhan, menambah fasilitas fotokopi, serta memperbaiki sikap dan komunikasi petugas dan dokter.

\section{DAFTAR RUJUKAN}

[1]. Irmawati. 2014. Manajemen Pemasaran Rumah Sakit. Surabaya: University Press

[2]. Ulfah, M., Rachmi, A.T., dan Yuniarinto, A. 2013. Pengaruh Bauran Pemasaran (Marketing Mix) terhadap Keputusan menggunakan Rawat Jalan di Rumah Sakit Bina Sehat Jember. Jember. Jurnal Aplikasi Manajemen. Vol. 11 No. 3. [Serial Online]. http://jurnaljam.ub.ac.id/index.ph p/jam /article /view /121 /592. [15 November 2016]

[3]. Jember. Rumah Sakit Daerah Kalisat. Profil Rumah Sakit Daerah Kalisat Kabupaten Jember Tahun
2017. Rumah Sakit Daerah Kalisat, 2016.

[4]. Radfan, N., Djumahir, dan Hariyanti, T. 2015. Pengaruh Bauran Pemasaran Terhadap Loyalitas Pasien di Poliklinik Paru Rumah Sakit Paru Batu. Batu Jurnal Aplikasi Manajemen (JAM). Vol. 13No. 2 [Serial Online]. http://jurnaljam.ub.ac.id/index.ph p/jam/article/view/763/722. [30 Oktober 2016]

[5]. Ariani, A., Rahyuda, K., dan Suprapti, N. W. S. 2016. Pengaruh Anteseden Kepuasan dan Loyalitas Pasien Rawat Inap di Rumah Sakit Dharma Kerti Tabanan. Bali. EJurnal Ekonomi dan Bisnis Universitas Udayana. Vol.5 No. 10 [Serial Online] https://ojs.unud.ac.id/ index.php/ EEB/article/view/23824.

Februari 2017]

[6]. Swastha, B., dan Irawan. 2008. Manajemen Pemasaran Modern. Yogyakarta: Liberty.

[7]. Poernomo, D. I. S. H. 2009. Analisis Pengaruh Persepsi Pasien tentang Bauran Pemasaran terhadap Loyalitas Pasien di Poliklinik Rawat Jalan Rumah Sakit Baptis Kediri. Tesis. Semarang : Fakultas Kesehatan Masyarakat Universitas Diponegoro.

[8]. Oktavia, S., Sudirman, dan Kadri, A. 2016. Hubungan Bauran Pemasaran (Marketing Mix) dengan Loyalitas Pelanggan di Laboratorium Klinik Prodia Palu. Palu. Promotif. Vol. 6 No. 1 [Serial Online]. http://jurnal.unismuhpalu.ac.id / index.php/PJKM/index. November 2017]

[9]. Wijayanti, S.W., A. M. Yusran, dan Indar. 2013. Artikel Bagian Administrasi dan Kebijakan 
Kesehatan Fakultas Kesehatan

Masyarakat Universitas

Hasanuddin. [Serial Online]. http ://repository.unhas.ac.id/ bitstream/handle/123456789/ 10414/ SHINTA\%20DEWI\% 20WIJAYANTI\%20K11110251.pdf; sequence $=1$. [27 April 2017]

[10]. Supriyanto, S., dan Ernawaty. 2010. Pemasaran Industri Jasa Kesehatan. Yogyakarta: Andi.

[11]. Rengkuan, S. R., Kandou, G. D., dan Tilaar, C. 2015. Hubungan Antara Persepsi Pasien Umum tentang Bauran Pemasaran Jasa dengan Loyalitas Pasien di Instalasi Rawat Jalan RS Advent Manado. Manado. JIKMU. Vol. 5 No. 1 [Serial Online] https://ejournal.unsrat.ac.id/ index.php/jikmu/ article/view/ 7174/6685. [30 Oktober 2017]

[12]. Solida, A. 2013. Hubungan Persepsi Bauran Pemasaran dengan Loyalitas Pasien di Klinik Kebidanan dan Kandungan Rumah Sakit Ibu dan Anak Kemang Medical Care tahun 2017. Skripsi. Jakarta: Fakultas Kedokteran dan Ilmu Kesehatan Universitas Islam Negeri Syarif Hidayatullah.
[13] Sembor, P. E. N., Posangi, J., Rattu, A. J. M., Kaunang, W. P. J. 2015. Hubungan antara Persepsi Pasien Umum tentang Bauran Pemasaran Jasa dengan Loyalitas Pasien di Unit Rawat Jalan Rumah Sakit Siloam Manado. Artikel Fakultas Kesehatan Masyarakat dan Fakultas Kedokteran Universitas Sam Ratulangi Manado. [Serial Online]. https://ejournalhealth.com/ index.php/t2/article/view/134. [26 November 2017]

[14]. Asmita, P. 2008. Analisis Pengaruh Persepsi Pasien tentang Mutu Pelayanan Dokter terhadap Loyalitas Pasien di Poliklinik Umum Instalasi Rawat Jalan Rumah Sakit Panti Wilasa Citarum Semarang Tahun 2008. Skripsi. Semarang : Fakultas Kesehatan Masyarakat Universitas Diponegoro. 